\title{
NEXUS BETWEEN EDUCATIONAL ATTAINMENTS AND CRIMINAL BEHAVIOR: A CASE STUDY OF PRISONS IN PUNJAB, PAKISTAN
}

\author{
Nouman Khaliq \\ PhD Scholar, \\ Department of Sociology \\ Government College University, Faisalabad \\ noumanmalik770@gmail.com \\ Muhammad Shabbir Chaudhary \\ Assistant Professor, Department of Sociology \\ Government College University, Faisalabad \\ Sadaf Mahmood \\ Assistant Professor, Department of Sociology \\ Government College University, Faisalabad \\ sadaf.mahmood88@yahoo.com
}

\begin{abstract}
The main objective of this research was to investigate the effect of intergenerational human capital accumulation on their criminal behavior if it existed. A multistage sampling technique was used for the selection of a sample of 400 respondents who have ever committed a crime and residing in district jails of Punjab, Pakistan. A well-designed interviewing schedule was used to collect information from these respondents. Descriptive analysis shows that majority of the respondents were young and married. Around one-fourth of the respondents were illiterate and about the same proportion had primary level education. The statistical analysis revealed that uneducated respondents had 40 percent more chances to commit the crime as compared to the educated ones. Thus, the set hypothesis that education is significantly affecting to discourage the criminal behavior in the society is upheld.
\end{abstract}

Key Words: Intergenerational, Human capital accumulation, Criminal Behavior, Punjab, Crime, District Jails of Punjab

\section{INTRODUCTION}

Crime is an act of violence and aggression against not only an individual but also against society as a whole. Crime is interconnected with human beings and is a prime concern for all human beings. It is considered social agreements of persons where rules of conduct are overlooked and in a serious breach, the violation was termed as crime and society undertook to punish the criminal since it was the responsibility of the society to protect the people. In its nature of universality, crime is viewed as an aspect of social action that poses threats to security and people's safety, their assets, their wellbeing, societal order and may reduce the life quality (Ntuli, 2000).

Education, as a potentially vital factor, is considered to help individuals refrain from committing obnoxious activities. Education helps individuals to enhance their capacity and abilities and providing opportunities to find an appropriate and legal mode of earnings in comparison with illegitimate earnings e.g., earnings from criminal activities. As schooling years increase, some specific types of street crimes are reduced to a reasonable extent (Lochner 2004). It is believed that with access to more resources and enhanced earnings, people tend to have fulfilled their basic needs with ease, therefore, avoid engaging themselves in criminal activities for the sole cause of earnings.

Numerous reasons established the fact that education positively affects crime reduction. Educational attainment equips the individuals with the necessary knowledge and skills to secure a legitimate work opportunity, thereby reducing the probability to engage in illegal and criminal activities for earnings and making it unattractive, too (Lochner, 2004). Secondly, education tends to directly affect individual's priorities, making them relatively more civilized, goal-oriented, and lawabiding. Altogether, such attributes lead to less likelihood of involving in criminal activities. Thirdly, 
school participation itself reduces the probability for individuals to indulge in criminal activities as they do have little spare time to spend in other activities. Conversely, with spending most of the time in schools, teenagers have more time to spend with peers, thus the opportunity to form some associations which may inspire them to indulge in deviant activities like exam-cheating, bullying, stealing, etc. However, educational reforms may help to affect peer associations and individuals' exposure to different acts under those peer compositions.

Several educational reforms or policy mechanisms may work to decrease deviant behavior over the life course of teenagers in schools. The more explicit attributive factor perhaps is educational attainment increases employment opportunities and legal earnings (Gould 2002). There is an established inverse relationship between educational attainment and criminal activities. Educational attainment is negatively associated with crime is fairly well established. Research findings indicate that drop-outs at junior school levels are predictably associated with deviant behavior (Thornberry et al., 1987). At the post-secondary level of education, evidence suggests that educational attainment with higher secondary level successfully prevents individuals from being involved in criminal activities and imprisonment. Arum and Lafree (2008) college-level educational attainment sufficiently provides the basis to reduce offending and other criminal behavior.

The role of schools in children's socialization significantly increases as they spend most of the time in educational settings as compared to family. Schools provide a platform to children during their life course where they witness and socialize the process of maturity. Most of the time adolescents struggle in proving their own identity while they interact with school administration and peers. This process of identity formation at school entails challenges that affect the sociopsychological domains of students. It is a fact that the moral development process starts and deepens at adolescent age. Through this process of moral development, they struggle to define what is right and wrong according to their mental approach and imagine their own identity and place in that moral space (Gilligan \& Kohlberg, 1988).

Educational attainment thus is a powerful tool not only in terms of affirmative socialization of adolescents especially in school settings but also a strong determinant in making an individual properly sensitized with the benefits of legitimate earnings and preventing him from adopting and engaging in deviant behavior.

\section{Rational of study}

Several research studies have concluded that illiterate and uneducated youth are prime prey to indulge in criminal activities due to their illiterate conditions (Pakistan Times, 2013). Illiteracy, peer group pressure, and loose execution of law enforcement are the adding factors that trigger the occurrence of criminal activities. The present study focused on the influence of educational attainment on criminal behavior. Over the last three decades, Pakistan has been facing the problems of terrorism, lawlessness, and, most importantly, an increasing rate of street crime, which is not only harmful to our cultural and religious values but also, has a negative impact as a whole for country's development. That's why the present study is not only important for the wellbeing and development of the country but also for the rehabilitation and wellbeing of the people involved in crimes. To overcome the underlying problems, solid future programs and plans are needed as corrective measures. Without comprehension of the unemployment rate and its determinants, the role of peer's influence in crime involvement, educational attainment, and other factors, the efforts to curb the crimes will remain in limbo. This research, therefore, aims to identify and determine the link, mainly, between educational attainment and crimes especially street crimes. Since this study's data were collected from different regions of Punjab province, so it was assured to represent all geographic characteristics of the province so that a clear picture of the problem may emerge. The findings of this study will potentially help decision-makers to envisage their strategies in a way that may yield targeted objectives in respect of decline in crime rate and improved security situations in the neighborhoods.

\section{Problem Statement /Research Question:}

This study was attempted to find answer of the research questions as whether educational attainment, socio-economic and ecological factors are associated with the occurrence of criminal behavior. Additionally, related questions like how and why these criminals offend will also be explored. 


\section{Objectives of the Study:}

This study entails the following objectives:

- To identify the socioeconomic and demographic characteristics of the respondents.

- To investigate the influence of educational attainment on criminal behavior.

- To suggest some policy measures to overcome the street crime.

\section{REVIEW OF LITERATURE}

Lochner \& Moretti (2004) found that education decreases the criminal behavior. To show that it is contributory and not absolute as individuals with higher education have supplementary qualities which keep them away from criminal activities, sociologists have studied modifications made in mandatory school leaving regulations that pressurize a number of individuals to continue schooling for more time beside they would decide willingly. These rules are then revealed to concurrently improve education and decrease criminal behavior.

Haider \& Ali (2015) studied various social and economic factors related to criminal behavior in every district of Pakistani Punjab for the period of 2010 to 2011. Chosen economic and social descriptive variables are education, density of population, joblessness, and transfer of funds, industrialization and predictor variable is crimes which were reported. Ordinary Least Square (OLS) technique was applied for experimental examination since the data as well as all variables accomplish the postulations of simple OLS. Results showed that density of population and joblessness has direct and important influence on criminal behavior. Education level and sum of transfer of funds are negatively associated to crimes in each district of Punjab. The outcomes showed that the most crowded and dense vicinities offer more likelihood for persons to carrying out offensive behavior.

Meghir et al., (2012) studied the impact of that reorganization on the male criminality straightly influenced due to the reorganization and also on the sons of those were affective. This intergenerational viewpoint is maybe main distinctive cause which positioned their study away from earlier writings. By means of a compact form measurement, Meghiret al., (2012) found 5\% decrease in probability of an associate of the reorganized cohort being criminal, with the powerful outcomes observed for the youth cohorts and that through nominal schooling of father and a $2.5 \%$ lower likelihood of their sons to become criminals.

Nordin (2018) predicted the consequence of tertiary education acceptability on felony in Sweden. The assumption tested is that ongoing to superior education reduces the rate of crimes because it let the adolescents to flee inactivity and joblessness, which are recognizing to start crime. On the other hand, to meet the criteria for tertiary education, persons have to fulfill the criteria need in upper-secondary school. Tertiary education acceptability criteria may consequently influence the rates of crime.

Ward \& van (2010) found that the likelihood of carrying out offenses as attack and injury shop lifting, threat and vandalism are indirectly associated with education. On the other hand, likelihood of carrying out tax evasion is directly associated with education. Additionally found that highly educated persons have more tolerant approach and social standards towards unlawful behavior.

\section{RESEARCH METHODOLOGY}

The province of Punjab, the universe for this study, has been classified into central, southern, and northern regions. All the district jails (prisons) in these three regions were taken as the population/universe for the study. A multi-stage sampling technique was used to achieve the sample size of 400 respondents who ever have committed a crime and are currently imprisoned in jail. At the first stage, three districts (Rawalpindi, Faisalabad, and Multan) were selected randomly. At the second stage, one jail from each district was selected randomly. A proportionate sampling frame was prepared for each selected district jail and a total sample of 400 prisoners/respondents was selected for collection of data through an interview schedule, covering the research objectives. Descriptive, bivariate and multivariate analyses were carried out on the collected data to draw inferences and conclusions. Logistic regression models were applied to assess the contribution of each independent variable in explaining the dependent variable in this study. As the dependent variable had dichotomous responses in addition to all independent variables, therefore, Logit regression estimation best suits the statistical analyses. 
RESULTS AND DISCUSSION

Table 1: Education status of the responders

\begin{tabular}{lll}
\hline Education & Frequency & Percent \\
\hline Illiterate & 113 & 28.3 \\
Primary & 102 & 25.5 \\
middle/Matric & 121 & 30.2 \\
Intermediate & 34 & 8.5 \\
Graduation & 30 & 7.5 \\
\hline Education of the Fathers of the Responders & \\
\hline Illiterate & 255 & 63.7 \\
Primary & 131 & 32.8 \\
Middle/Matric & 14 & 3.5 \\
\hline Opinion of the respondents regarding illiteracy as a factor of criminal behavior \\
\hline To great extent & 237 & 59.3 \\
To some extent & 54 & 13.5 \\
Not at all & 109 & 27.2 \\
\hline
\end{tabular}

Opinion of the Responders about the extent to which unequal education structure is

Responsible for crimes

\begin{tabular}{lll}
\hline To Great extent & 202 & 50.5 \\
To Some extent & 139 & 34.8 \\
Not At all & 59 & 14.7 \\
\hline
\end{tabular}

Opinion responders about the extent to which educational disparities are responsible to

Push the people towards crime

\begin{tabular}{lll}
\hline \multicolumn{1}{c}{ Response category } & Frequency & Percent \\
\hline To Great extent & 160 & 40.0 \\
To Some extent & 213 & 53.2 \\
Not At all & 27 & 6.8 \\
\hline Total & $\mathbf{4 0 0}$ & $\mathbf{1 0 0 . 0}$ \\
\hline
\end{tabular}

Education is extremely vital for a child as it organizes skills and abilities to do critical thinking regarding his future practical life. It is a process which enables the child to adapt properly in his social environment and to live a proper social life. Terminating the basic and compulsory schooling would be eventually a abandoning the majority of the youngsters, leaving the maim less and struggling violently to attain even an ordinary living standard which forced them towards crimes. The data in Table-1 indicates that 28\% responders were Illiterate and education level of $26 \%$ of the respondents was primary. Whereas, $30 \%$ respondents were Middle/Matric, $9 \%$ had intermediate level of education and only $8 \%$ had graduation or higher educational level. The statistics vividly showed that majority of the respondents was illiterate or had lower level of education. Illiteracy of the parents is one of major causes of crime rate in Pakistan. Deficiency of literacy and unawareness of parents and they adopt approaches regarding education of their children are very important reasons which are contributing to crime rate. Table 1 also illustrates that huge number i-e. $64 \%$ or respondents' fathers were illiterate while education of one-thirds was of primary level. A very low proportion of the respondents' fathers (4\%) possessed Middle/Matric level education. This clearly shows that stunning majority of fathers of the criminals were illiterate or had just primary level of education. The results of this table are similar as of Patterson (1991) who affirmed that education of parents' educational level decreases aggressive activities amongst their offspring's.

People with lower literacy level are likely to be fewer dynamic members of the society as compare to highly educated persons. These types of people have lesser probability of their involvement in sports, welfare, entertainment, community development and so on. Resultantly, they usually feel loneliness and helpless, and several of them feel like outsiders. This type of situation is very ideal for involving one in criminal activities. Table 2 points out that major portion $(59 \%)$ of responders were agreed that illiteracy is the major factor to great extent behind the criminal behaviors. Whereas, $14 \%$ of responders were of the opinion that illiteracy is a factor of criminal behavior but to 
some extent and $27 \%$ said the illiteracy do not play any role in criminal behavior. It is apparent from these results that majority of the respondents were agreed that illiteracy plays a vital role in criminal behavior.

Half of the responders were of the opinion that structure of unequal education is responsible for crimes to great extent and about one-third respondents were in the favor of this statement to some extent. Only 15\% said that unequal structure of education did not responsible for crimes. Results of Sabates et al(2008) study are similar to these results which show that higher degree of unequal education structure among cohorts were linked with higher rates of crime.

Further, Table 2 shows that $40 \%$ of the respondents were of the opinion that educational disparities are responsible to some extent to push the people towards crime whereas, about half of the respondents said that educational disparities were responsible for crimes to great extent. Only $7 \%$ said that educational disparities were not at all responsible to push the people towards crimes. Results of this table clearly show that majority of the respondents think that educational disparities are more likely to a dominant factor of indulging and pushing the people towards crime. Sabates et al., (2008) also established evidence of an association among educational disparity and crime rates for violent among youth with higher levels of disparity linked with higher levels of crimes.

Table 3: Association between Education of the respondents and their opinions (to great extent, to some extent and not at all) regarding different statements

\begin{tabular}{|c|c|c|c|c|c|}
\hline Statements/Opinion & $\begin{array}{l}\text { Chi- } \\
\text { square }\end{array}$ & p-value & Statements/Opinion & $\begin{array}{l}\text { Chi- } \\
\text { square }\end{array}$ & p-value \\
\hline Illiteracy & 15.56 & .049 & $\begin{array}{l}\text { Media is responsible to push } \\
\text { the youth in crimes }\end{array}$ & 14.368 & .006 \\
\hline Media & 49.29 & .000 & $\begin{array}{l}\text { in rural areas Land disputes } \\
\text { promote criminal behavior }\end{array}$ & 214.806 & .000 \\
\hline Improper socialization & 43.871 & .000 & $\begin{array}{l}\text { Water disputes are the reason } \\
\text { of criminal behavior in rural } \\
\text { areas }\end{array}$ & 50.807 & .000 \\
\hline Peer group & 60.072 & .000 & $\begin{array}{l}\text { Job-loss Factors which } \\
\text { leads youth towards crime }\end{array}$ & & \\
\hline Broken homes & 10.931 & .206 & Political instability & 130.694 & .000 \\
\hline Poverty & 41.065 & .000 & Corruption & 52.610 & .000 \\
\hline $\begin{array}{l}\text { Cheap movies and } \\
\text { literature }\end{array}$ & 54.021 & .000 & Money laundering & 42.851 & .000 \\
\hline Unemployment & 52.961 & .000 & Nepotism & 72.893 & .000 \\
\hline $\begin{array}{l}\text { Politicized law } \\
\text { enforcing agencies are } \\
\text { responsible to enhance } \\
\text { crime among youth }\end{array}$ & 161.720 & .000 & Foreign loans and aid & 78.947 & .000 \\
\hline $\begin{array}{l}\text { un-equal educational } \\
\text { structure re is } \\
\text { responsible for crimes }\end{array}$ & 90.431 & .000 & $\begin{array}{l}\text { Factors can control the } \\
\text { deviant behavior }\end{array}$ & & \\
\hline Disparities & & & Strong family institution & 77.352 & .000 \\
\hline Economic & 30.472 & .000 & Economic development & 27.031 & .000 \\
\hline Educational & 44.249 & .000 & Social justice & 38.147 & .000 \\
\hline Gender & $52.744^{\mathrm{a}}$ & .000 & Merit in all fields & 59.747 & .000 \\
\hline Social & $71.783^{\mathrm{a}}$ & .000 & Spots and recreations & 76.301 & .000 \\
\hline Justice & 75.499 & .000 & Islamic punishments & 22.856 & .000 \\
\hline Employment & 96.330 & .000 & & & \\
\hline Health & 114.663 & .000 & & & \\
\hline
\end{tabular}


regarding media, improper socialization, peer group, broken homes, poverty, cheap movies/literature and unemployment. The results further show that there is a significant relationship between education of the responders and their opinion regarding economic, educational, gender, social, justice, employment and health disparities as the causes to push the people towards crimes. There is also a significant association between education of the responders and their opinion regarding media as a source to push the youth towards crime. This result is matching to the findings of Marsh \& Melville (2014) who found that media is pushing innocent youth to commit crime. Similarly, there is a highly significant association among education and opinion of the responders that land and water disputes tend to promote criminal behavior among rural people. Results also indicate a meaningful relationship between education and opinion of the responders that political instability, corruption, money laundering, nepotism and foreign loans/aid are the causes of job logjam which direct youth toward crimes.

The results also show that there is a significant relationship between education and opinion of the responders that strong family institution, economic development, social justice, sports and recreations and Islamic punishments could play a vital role to control the crimes.

Table 4: Association between Father's Education of the respondents and their opinions (to great extent, to some extent and not at all) regarding different statements

\begin{tabular}{|c|c|c|c|c|c|}
\hline Statements/Opinion & $\begin{array}{l}\text { Chi- } \\
\text { square }\end{array}$ & p-value & Statements/Opinion & $\begin{array}{l}\text { Chi- } \\
\text { square }\end{array}$ & p-value \\
\hline Illiteracy & 32.067 & .000 & $\begin{array}{l}\text { Media is responsible to push } \\
\text { the youth in crimes? }\end{array}$ & 29.162 & .000 \\
\hline Media & 46.765 & .000 & $\begin{array}{l}\text { in rural areas Land disputes } \\
\text { promote criminal behavior }\end{array}$ & 98.685 & .000 \\
\hline Improper socialization & 29.716 & .000 & $\begin{array}{l}\text { water disputes are the reason } \\
\text { of criminal behavior in rural } \\
\text { areas }\end{array}$ & 57.007 & .000 \\
\hline Peer group & 16.351 & .003 & $\begin{array}{l}\text { Job-loss Factors which leads } \\
\text { youth towards crime }\end{array}$ & & \\
\hline Broken homes & 32.794 & .000 & Political instability & 42.831 & .000 \\
\hline Poverty & 10.792 & .029 & Corruption & 21.306 & .000 \\
\hline $\begin{array}{l}\text { Cheap movies and } \\
\text { literature }\end{array}$ & 35.659 & .000 & Money laundering & 45.718 & .000 \\
\hline Unemployment & 27.415 & .000 & Nepotism & 119.701 & .000 \\
\hline Politicized law & 20.891 & .000 & Foreign loans and aid & 179.285 & .000 \\
\hline
\end{tabular}

responsible to enhance

crime among youth

un-equal educational

structure is responsible

$76.951 \quad .000$

Factors can control the deviant behavior

for crimes

\section{Disparities}

Economic

Educational

Gender

Social

Justice

Employment

Health

$\begin{array}{cc}50.090 & .000 \\ 55.474 & .000 \\ 67.110 & .000 \\ 66.926 & .000 \\ 79.026 & .000 \\ 31.089 & .000 \\ 45.516 & .000\end{array}$

Strong family institution

Economic development

Social justice

Merit in all fields

Spots and recreations

Islamic punishments

Table 4 depicts the results of Pearson chi-square test which was employed to explore the association between respondents' father education and their opinions (to great extent, to some extent and not at all) regarding different statements. The results show that there is significant relationship between respondents' father education and their opinion that illiteracy is the factor to push the people towards criminal behavior. Similarly, there is a significant relationship between respondents' father education and media, improper socialization, peer group pressure, broken homes, poverty, cheap 
movies/literature and unemployment. The results further show that there is a significant relationship between respondents' father education and their opinion regarding economic, educational, gender, social, justice, employment and health disparities as the causes to push the people towards crimes. There is also a significant association between respondents' father education and their opinion regarding media as a source to push the youth towards crime. Similarly, there is a highly significant association among the respondents' father education and their opinion that land and water disputes promote criminal behavior among rural people. Results also indicate a meaningful relationship between education of respondents' father and their opinion that political instability, corruption, money laundering, nepotism and foreign loans/aid are the causes of joblessness which direct youth toward crimes.

The results also show that there is a significant relationship between education of father and opinion of the responders that strong family institution, economic development, social justice, sports and recreations and Islamic punishments could play a vital role to control the crimes.

\section{CONCLUSION}

This paper studies the relationship between educational attainment and criminal behavior of people in Punjab, Pakistan. The results show that there is a significant relationship between education of the responders and their opinion regarding economic, educational, gender, and social, justice, employment and health disparities as the causes to push the people towards crimes. There is also a significant association between education of the respondents and their opinion regarding media as a source to push the youth towards crime. This result is matching to the findings of Marsh \& Melville (2014) who found that media is pushing innocent youth to commit crime. Similarly, there is a highly significant association among the education and opinion of the responders that land and water disputes promote criminal behavior among rural people. Results also indicate a meaningful relationship between education and opinion of the respondents that political instability, corruption, money laundering, nepotism and foreign loans/aid are the causes of job logjam which direct youth toward crimes. The education of father was significantly related to the non-involvement of individuals in crime.

\section{RECOMMENDATIONS}

- It is suggested that by providing disadvantaged urban as well as rural youth with free and better education can substantially reduce crime among youth. Better education may deliver large societal benefits and can be a major policy instrument to reduce crime.

- To reduce the incidence of crimes, the government should try to create economic opportunities for the illiterate and less educated people. For this purpose, the private sector should also be engaged to provide more job opportunities. Also, less educated people may be equipped with practical training of various occupational skills so that they may become selfemployed and don't become a burden on their families and ultimately for government and society for prevention of crimes.

- Govt. should make a comprehensive national action plan, execute and supervise it. Integrate crime evasion into educational and social policies, and in this way end or social equality. In developing countries like Pakistan education can play a vital role to control the criminal behavior because people with higher education have more tolerant approaches and social norms towards criminal behavior. Therefore, considerable funds on the social expenses of crime can be achieved by investing in education.

\section{REFERENCES}

Arum, R., \& LaFree, G. (2008). Educational attainment, teacher-student ratios, and the risk of adult incarceration among US birth cohorts since 1910. Sociology of Education, 81(4), 397-421.

Gould, E. D., Weinberg, B. A., \& Mustard, D. B. (2002). Crime rates and local labor market opportunities in the United States: 1979-1997. Review of Economics and statistics, 84(1), 4561.

Haider, A., \& Ali, A. (2015). Socio-economic determinants of crimes: a cross-sectional study of Punjab districts. International Journal of Economics and Empirical Research, 3(11), 550-560. 
Lochner, L and E Moretti (2004) "The Effect of Education on Crime: Evidence from Prison Inmates, Arrests and Self-reports", American Economic Review, 94: 155-89.

Lochner, Lance. "Education and crime." The economics of education. Academic Press, 2020. 109117.

Marsh, I., \& Melville, G. (2019). Crime, justice and the media. Routledge.

Meghir, C., Palme, M., \& Schnabel, M. (2012). The effect of education policy on crime: an intergenerational perspective (No. w18145). National Bureau of Economic Research.

Nordin, M. (2018). Does eligibility for tertiary education affect crime rates? Quasi-experimental evidence. Journal of quantitative criminology, 34(3), 805-829.

Ntuli, T.G. (2000). Impact of crucial victimization. South Africa: University of Zululand.

Pakistan Times, (2013). Street crime on rise. Retrieved from. http:@www.pstimes.com.

Patterson, E. B. (1991). Poverty, income inequality, and community crime rates. Criminology, 29(4), $755-776$

Quenelle, A. (1984). Adolph Quenelle's research on the propensity for crime at different ages. New York: Anderson Publishing Company.

Sabates, R., Feinstein, L., \& Shingal, A. (2008). Educational Inequality and Juvenile Crime:An Areabased Analysis. Leon and Shingal, Anirudh, Educational Inequality and Juvenile Crime: An Area-Based Analysis (February 1, 2008).

Thornberry, T. P. (1987). Toward an interactional theory of delinquency. Criminology, 25(4), 863892.

Ward, K. C., Kirchner, E. E., \& Thompson, A. J. (2010). Social disorganization and rural/urban crime rates: A county level comparison of contributing factors. 